\title{
МЕТОДЫ УВЕЛИЧЕНИЯ НЕФТЕОТДАЧИ НА МЕСТОРОЖДЕНИЯХ ЮГРЫ
}

\author{
Кузьменков Станислав Григорьевич 1 , \\ ksg.1948@ya.ru
}

\author{
Аюпов Роман Шамильевич1, \\ ayupovrsh@gmail.com
}

Новиков Максим Васильевич2,
NovikovMV@admhmao.ru

Исаев Валерий Иванович, isaevvi@tpu.ru

1 Югорский государственный университет, Россия, 628012, г. Ханты-Мансийск, ул. Чехова, 16.

2 Департамент недропользования и природных ресурсов Ханты-Мансийского автономного округа-Югры, Россия, 628007, г. Ханты-Мансийск, ул. Студенческая, 2.

3 Национальный исследовательский Томский политехнический университет, Россия, 635050, г. Томск, пр. Ленина, 30.

4 АУ «Научно-аналитический центр рационального недропользования им. В.И. Шпильмана», Россия, 628007, г. Ханты-Мансийск, ул. Студенческая, 2.

\author{
Лобова Галина Анатольевна 3 , \\ lobovaga@tpu.ru
}

Стулов Пётр Александрович 4 , StulovPA@nacrn.hmao.ru

Бутин Виталий Сергеевич4, butinvs@nacrn.hmao.ru

\section{Астапенко Елена Олеговна', fedorov-elena@yandex.ru}

Актуальность. Государственным балансом запасов в Югре учтено 482 месторождения углеводородного сырья (порядка 12 млрд m извлекаемых запасов). 273 месторождения находятся в разработке, а 210 - на различных этапах исследования. Текущая выработанность месторождений составляет 61 \%, а их текущая обводненность - выше 85 \%. Современный этап характеризуется снижением добычи практически на всех объектах нефртедобычи и увеличением до 65-70 \% доли трудноизвлекаемых запасов. Главной задачей предприятий ТЭК Югры - основной базы углеводородного сырья и нефтедобычи России является стабилизация добычи нефти на достигнутом в 2018 г. уровне в 235-236 млн m/год. Решение этой задачи невозможно без применения инновационных технологий повышения нефттеотдачи пластов.

Цель: анализ эффрективности (с точки зрения дополнительной добычи) внедренных в производственном режиме третичных технологий повышения коэфффициента извлечения нефти на месторождениях Югры.

Объект: особенности методов увеличения нефтеотдачи и их геолого-промысловые результаты на месторождениях Югры (2013-2019 ге.): ффизико-химических, гидродинамических, гидроразрыва пласта, бурения горизонтальных скважин, зарезки боковых стволов, обработки призабойной зоны, а также прочих методов - геолого-технологических мероприятий по оптимизации работы фонда скважин.

Методы: ретроспективный сопоставительный анализ выполненных скважино-операций методов увеличения нефтеотдачи и дополнительной добычи нефрти: физико-химических - 48016, гидродинамических - 23374, гидроразрыва пласта - 28454 , бурения горизонтальных скважин - 11225, зарезки боковых стволов - 9010, обработки призабойной зоны - 44081, геологотехнологических мероприятий - 32123 операции.

Результаты. Анализировались геолого-промысловые и отчетно-статистические данные Научно-аналитического центра рационального недропользования им. В.И. Шпильмана и Департамента по недропользованию ХМАО-Югры. В Югре наметилась тенденция стабилизации годовой добычи нефрти. При этом доля дополнительной добычи нефтти за счет применения методов увеличения нефттеотдачи и геолого-технологических мероприятий увеличилась с 9,4 \% в 2013 г. до 16,0 \% в 2019 г. Наиболее массовыми методами интенсификации добычи и повышения нефртеотдачи являются физико-химические, обработки призабойной зоны и гидродинамические. Самыми эфффективными методами, обеспечивающими дополнительную добычу, являются: бурение горизонтальных скважин, зарезка боковых стволов и гидроразрыв пласта. Массовое применение методов увеличения нефтеотдачи на разрабатываемых месторождениях требует усиления научного-технического обоснования оптимальных условий строительства и эксплуатации систем разработки. Доля трудноизвлекаемых запасов нефрти составляет в среднем около 60 \%, а по некоторым компаниям достигает 75-80 \%, поэтому альтернативы развитию третичных методов повышения нефттеотдачи на месторождениях Югры сегодня нет.

\section{Ключевые слова:}

Трудноизвлекаемые запасы, коэффрициент извлечения нефти, методы увеличения нефтеотдачи, ретроспективный анализ, Югра.

\section{Введение}

В августе 2019 г. в Ханты-Мансийске (ХантыМансийский автономны округ-Югра) под эгидой Минприроды РФ состоялось совещание [1], на кото- ром во всех выступлениях было отмечено, что эпоха легкоизвлекаемой нефти подходит к концу.

В частности, министр Минприроды РФ Д.Н. Кобылкин отметил, что «на сегодня вопросы стимулирования внедрения нестандартных методов увеличе- 
ния нефтедобычи в действующей системе налогообложения становятся весьма актуальными».

Губернатор Югры Н.В. Комарова предложила использовать Югру в качестве пилотного региона для апробации, внедрения, тиражирования новых технологий повышения нефтеотдачи. Главной целью Югра видит перед собой «становление в качестве поставщика технологий, химических реагентов и высококвалифицированных кадров, в т. ч. на мировые рынки», при этом у округа для этого «есть возможность выстроить современную систему работы» [1].

В то же время сегодня, помимо недостаточности эффективных технологических подходов разработки недр, остро встает вопрос обеспечения указанных технологий отечественным оборудованием и комплектующими. Их разработка, апробация конкретных технологий в условиях реальных полигонов и запуск в серийное производство позволят в дальнейшем осуществлять ввод в промышленный оборот не введенные в разработку, нерентабельные сегодня, мелкие месторождения и трудноизвлекаемые запасы (ТрИЗ), что актуально сегодня не только для Югры, но и для России в целом.

Государственным балансом запасов полезных ископаемых на 01.01.2019 в РФ учтено 3131 месторождение с суммарными технологически извлекаемыми запасами нефти порядка 30 млрд т, 74 \% из которых приходится на Уральский федеральный округ (17 млрд т), в т. ч. 52 \% (порядка 12 млрд т) сосредоточено в Югре.

По данным Государственной комиссии по запасам (ГКЗ) в России в разработку введено $45 \%$ от всего открытого потенциала минерально-сырьевой базы РФ по нефти, остальные $55 \%$ - не вовлечены в разработку из-за низкой экономической эффективности, отсутствия инфраструктуры и/или необходимых технологий добычи. При этом 80 \% неразрабатываемых месторождений открыто более 10 лет назад, а 45 \% в конце прошлого века.

Аналогичная ситуация характерна и для Югры. Государственным балансом в Югре учтено 482 месторождения углеводородного сырья, в том числе: 419 нефтяных, 23 нефтегазоконденсатных, 18 газовых, 5 газоконденсатных, 17 газонефтяных. 273 месторождения находятся в разработке, а 210, или 44 \% от общего количества открытых месторождений, - на различных этапах исследования. Следует отметить, что текущая выработанность месторождений составляет $61 \%$, а их текущая обводненность - выше $85 \%$.

Сегодня нефтегазовый сектор Югры находится в стадии стабилизации добычи нефти. Если в целом по РФ за 2018 г. добыча составила 555,8 млн т, что на $1,7 \%$ больше добычи в 2017 г., то в Югре добыто 236453,4 тыс. т нефти, или 42,5 \% общероссийской добычи. В 2018 г., относительно 2017 г., добыча в округе увеличилась на 0,5 \%, или на 1172,6 тыс. т в абсолютных единицах. На конец 2019 г. (ноябрь) накопленная добыча нефти на месторождениях Югры составила 11 876,4 млн т. Весной 2020 г. в Югре ожидается добыча 12-ти миллиардной тонны нефти.
По данным Департамента недропользования и природных ресурсов Ханты-Мансийского автономного округа-Югры (Депнедра Югры), извлекаемые запасы нефти распределенного фонда недр (РФН) Югры категории $\mathrm{AB}_{1} \mathrm{~B}_{2}+\mathrm{C}_{1} \mathrm{C}_{2}$ по состоянию на 01.01.2019 составляют 11,935 млрд т, из них доля нерентабельных для разработки в современных экономических условиях достигает более 3, 5 млрд т (рис. 1). При этом в подсчете не учитываются запасы нераспределенного фонда недр (НРФН) и не введенные в разработку в пределах РФН залежи и месторождения.

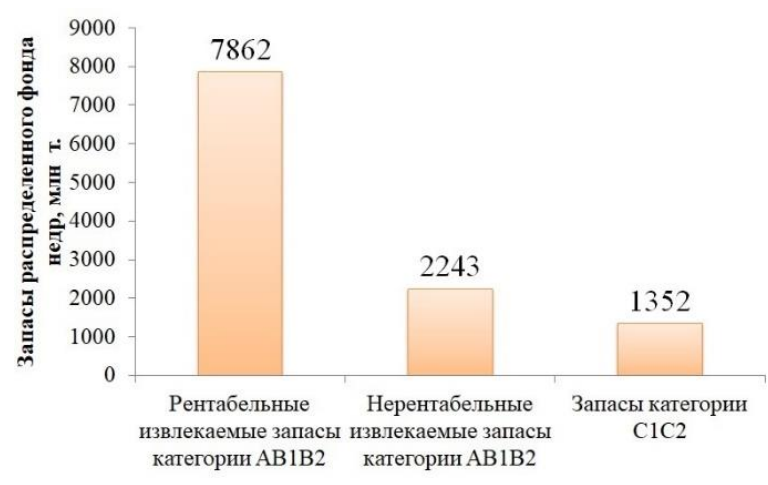

Puc. 1. Запасы нефти распределенного фонда недр Югры (Департамент недропользования и природных ресурсов Ханты-Мансийского автономного округа-Югры, 01.01.2019)

Fig. 1. Oil reserves of distributed subsurface resources of Yugra (Department of Subsurface Management \& Natural Resources of Khanty-Mansi Autonomous Okrug-Yugra, 01.01.2019)

О наращивании ресурсной базы нефти и стабилизации добычи в Югре, о методах увеличения нефтеотдачи

Значительным резервом для развития отрасли и изменения отрицательного тренда добычи нефти остаются запасы уже эксплуатируемых месторождений, имеющих значительный потенциал остаточных запасов, а также запасы и ресурсы месторождений, открытых, но экономически нерентабельных для вовлечения в полномасштабную разработку в условиях действующей налоговой системы.

За 55 лет (1964-2019 гг.) разработки нефтегазовых месторождений в Югре выделяется пять периодов [2]: 1-й - (1964-1982 гг.) растущей, 2-й - (1983-1988 гг.) стабильной, 3-й - (1989-1996 гг.) падающей, 4-й (1997-2007 гг.) вновь возрастающей добычи нефти и 5-й - (2008-настоящее время), характеризующийся снижающейся добычей со стабилизаџией в последние два года. На рис. 2 представлена динамика добычи нефти, ввода новых скважин и объемов эксплуатационного бурения.

Высокому уровню добычи нефти в округе в свое время способствовало освоение и ввод в разработку крупных месторождений с высокопродуктивными залежами, а резкое снижение добычи в третьем периоде объясняется распадом СССР и сменой социально-экономической формации в России. Представляется, что и в этот сложный для страны период си- 
бирские геологи и нефтяники с честью выполнили свой профессиональный долг, сохранив крупнейший в стране нефтегазовый комплекс, что позволило России с минимальными потерями преодолеть этот кризисный период. Современный этап разработки нефтегазоконденсатных месторождений Югры [3] характеризуется снижением добычи практически на всех объектах нефтедобычи и увеличением до 65-70 \% на них доли ТрИЗ.

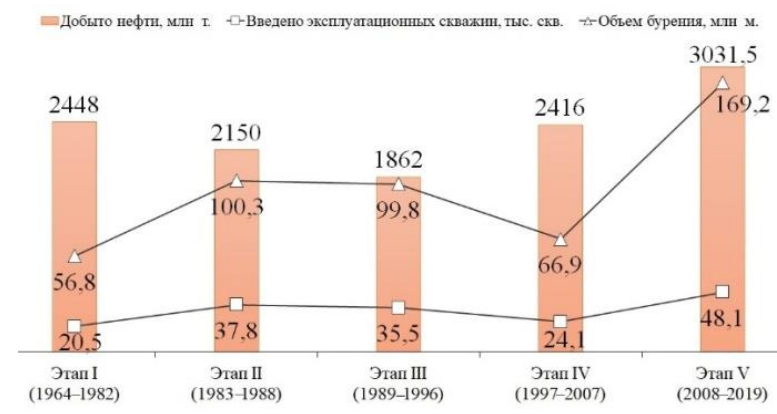

Pис. 2. Этапь разработки месторождений углеводородного сырья на территории Югры (по [2], с дополнениями)

Fig. 2. Stages of raw hydrocarbons fields development in the territory of Yugra (by [2], with additions)

Пути наращивания ресурсной базы нефти и стабилизации добычи в Югре связаны с несколькими направлениями, включая:

1) расширение географии поисково-оценочных работ в перспективных малоизученных районах (поисковых зон), открытие месторождений;

2) постановку обобщающих тематических исследований по детальной переобработке и переинтерпретации геолого-геофизической информации, направленных на выявление «пропущенных» залежей, причем это касается и территорий активной нефтедобычи;

3) создание опытных научных полигонов для внедрения технологий поиска, разведки, исследований, подсчета запасов залежей трудноизвлекаемой нефти, и, в первую очередь, баженовской свиты;

4) освоение ТрИЗ, в т. ч. залежей ачимовской, баженовской, абалакской, тюменской свит, тяжелой нефти сеномана;

5) увеличение коэффициента извлечения нефти (КИН) за счет масштабного применения методов увеличения нефтеотдачи (МУН) пласта и методов интенсификации притока жидкости на высоковыработанных и высокообводненных месторождениях.

Не станем останавливаться на первых четырех эти направления были достаточно полно рассмотрены ранее в работах $[3,4]$, а остановимся на анализе эффективности и проблемах применяемых в Югре известных методов повышения КИН [5-7].

На сегодня главной задачей предприятий ТЭК Югры является стабилизация добычи нефти на достигнутом в 2018 г. уровне в 235-236 млн m/год. Peшение этой задачи невозможно без применения современных технологий повышения нефтеотдачи пла- стов. Значительным резервом для развития отрасли и изменения отрицательного тренда добычи нефти остаются запасы уже эксплуатируемых месторождений, имеющих значительный потенциал остаточных запасов, а также запасы и ресурсы месторождений открытых, но экономически нерентабельных в условиях действующей налоговой системы. Но без применения новых эффективных технологий повышения КИН задача вовлечения ТрИЗ в активную разработку затруднена [4].

Сегодня существует огромное число методов увеличения нефтеотдачи пластов и методов интенсификации добычи нефти, конечной целью которых является повышение коэффициента извлечение нефти. Как было отмечено выше, в Югре в 2020 г. ожидается добыча 12-ти миллиардной тонны нефти при текущем КИНе на уровне 0,37 [8]. При этом, по расчетам специалистов АУ «НАЦ РН им. В.И. Шпильмана», повымение КИН на 0,1 позволит дополнительно добыть более 4,0 млрд т нефти на уже разрабатьваемых месторождениях Югры.

Таким образом, методы увеличения нефтеотдачи являются одним из перспективных направлений стабилизации добычи нефти, а широкомасштабное их внедрение на разрабатываемых месторождениях может дать «вторую жизнь» ТЭК Западной Сибири.

Учитывая значимость и актуальность поднятых на упомянутом выше совещании вопросов [1], нами был проведен анализ эффективности внедренных в производственном режиме новых технологий повышения КИН в Югре. В 2018 г. в результате применения МУН и интенсификации добычи дополнительно получено 35797,6 тыс. т нефти, что составляет 15,1 \% от общего объема добытой в 2018 г. нефти в округе (рис. 3).

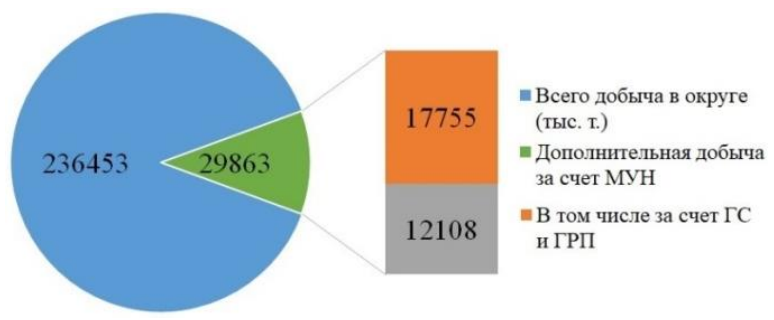

Pис. 3. Добыча нефти в Югре в 2018 г. Добыча за счет применения МУН, включая бурение горизонтальных скважин (ГС) и гидроразрыв пласта (ГРП)

Fig. 3. Oil production in Yugra in 2018. Production due to application of Enhanced Oil Recovery (EOR) methods including horizontal drilling (HD) and hydraulic fracturing $(H F)$

Сегодня большая часть месторождений Югры находится на третьей-четвертой стадиях разработки, когда традиционные методы добычи за счет естественной энергии пласта и регулирования пластового давления путем закачки в залежь воды (заводнение) и/или газа становятся неэффективными. Необходимым условием повышения КИН приобретают методы увеличения нефтеотдачи пластов. Ниже проведен анализ применения МУН за период с 2013 г. по настоящее время (рис. 4). 


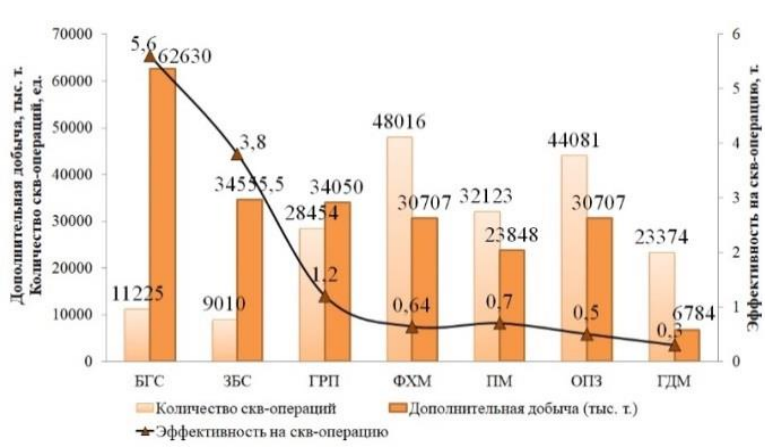

Pис. 4 Дополнительная добыча нефти на разрабатываемых месторождениях Югры за счет применения МУН и интенсификации добычи (с 2013 по 2019 гг., данные за 2019 г. - ожидаемые)

Fig. 4. Additional oil production at producing fields of Yugra due to EOR methods application and intensification of production (since 2013 to 2019, data for 2019 - expected)

В целом эффективность добычи нефти даже с применением МУН следует считать неудовлетворительной, так как средняя нефтеотдача в Югре колеблется от 25 до $40-45 \%$. Поэтому сегодня на первый план выносятся задачи внедрения в производство современных технологий нефтедобычи, нацеленных на увеличение КИНа на разрабатываемых месторождениях, где традиционными методами извлечь остаточные запасы (55-75 \% от начальных извлекаемых) нефти невозможно.

Среди МУН, направленных на увеличения КИНа, в Западной Сибири можно выделить тепловые, газовые, физико-химические (ФХМ), гидродинамические (ГДМ) методы, ГРП, бурение горизонтальных скважин (БГС), зарезку боковых стволов (ЗБС), обработку призабойной зоны (ОПЗ). В отдельный блок прочих методов (ПМ) интенсификации добычи следует отнести дострелы, перестрелы, возвраты на вышележащие пласты, приобщения пластов, изоляционные работы, интенсификацию добычи за счет снижение депрессии на пласт, а также работа с фондом скважин, оптимизацию и перевод работы скважин на механическую добычу.

Рассмотрим более подробно методы, применяемые в значимых объемах.

\section{Физико-химические методы}

Технологии ФХМ базируются на заводнении для регулирования (ограничения) и/или изоляции притока воды [5, 9]. ФХМ используются для дополнительной добычи нефти из пластов, которые характеризуются сильным истощением, обводненностью, а также из тех частей залежи, которые имеют рассеянную и нерегулярную нефтенасыщенность. Основным компонентом при применении методов является вода с примесью химических реагентов.

На сегодняшний день в практике применяется свыше 30 технологий повышения нефтеотдачи путем химического воздействия, но наиболее эффективным, по мнению специалистов - нефтяников, является трехфазное химическое заводнение - совместное применение щелочи, водных растворов поверхностно активных веществ (ПАВ) и полимера. При этом щелочь способствует увеличению смачиваемости породы водой, ПАВ способствует снижению поверхностного натяжения нефти, а полимер - увеличению вязкости агента. В применяемой композиции основную «стабилизирующую» роль играет щелочь, которая многократно снижает оседание ПАВ на породе, а при реакции с нефтью в самом пласте создаются дополнительные ПАВ, что в конечном итоге существенно (в 5-10 раз) снижает расход ПАВ. Рост КИН, по данным модельных испытаний, проведенных в различных исследовательских группах, варьирует от 15 до $25 \%$.

На рис. 5 представлен анализ проведения ФХМ на месторождениях Югры, из которого следует, что за семь лет было проведено более 48 тысяч скважиноопераций (скв-операций). За счет этого добыто дополнительно 30707 тыс. т нефти.

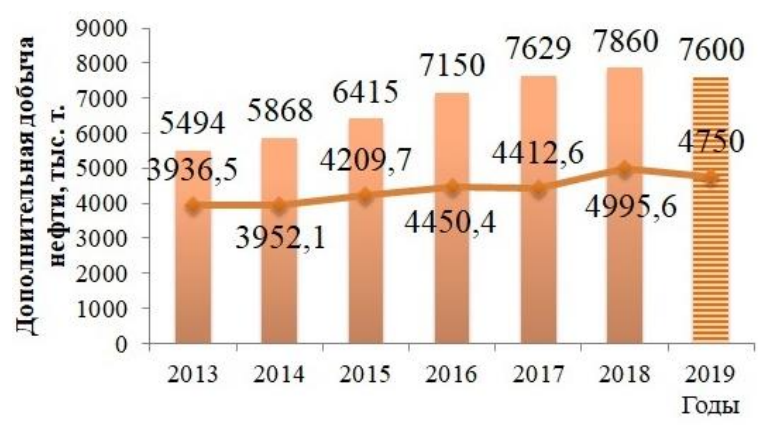

- Скв-операций —Дополнительная добыча нефти, тыс. т.

Pис. 5. Динамика скважино-операций и дополнительной добычи нефти за счет применения физикохимических МУН на месторождениях Югры (с 2013 по 2019 ге., данные за 2019 г. - ожидаемые)

Fig. 5. Dynamics of well operations and additional oil production due to application of physical and chemical EOR methods at the fields of Yugra (since 2013 to 2019, data for 2019-expected)

\section{Гидродинамические методы}

Сегодня в Югре заводнение является основным технологическим приемом разработки месторождений, однако его эффективность снижается из-за осложняющих добычу факторов, таких как вынос механических примесей, отложения парафинов, гидратов и др. Нефтяниками ТЭК Югры, наряду с традиционным заводнением, в массовом масштабе используются гидродинамические методы: форсированный отбор жидкости, увеличение и/или ограничение закачки воды. Самая востребованная технология ГДМ метод циклического заводнения (ЦЗ) - характеризуется высокой эффективностью, дешевизной и незначительными технологическими усилиями для внедрения на промыслах.

На сегодня существует более 400 потокоотклоняющих технологий (ПОТ) [10-13], но в производственном режиме используется около ста. Проведенный ретроспективный анализ за период 2013-2019 гг. показал (рис. 6), что эффективность ГДМ значитель- 
но ниже ожидаемой, особенно в осложненных геолого-физических условиях месторождений Западной Сибири, и требуют совершенствования. Эффективность ГДМ доказана в условиях фильтрационноемкостной неоднородности коллектора, когда в объектах разработки (пластах) показатели проницаемости разнятся в разы и более.

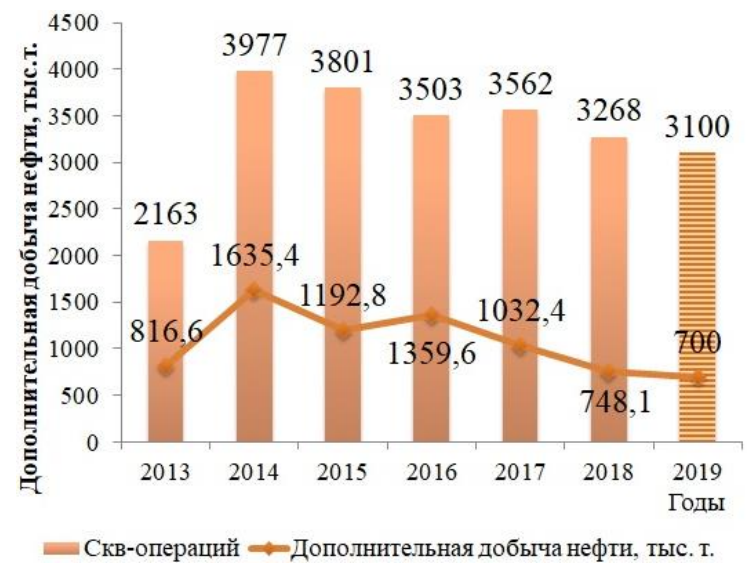

Рис. 6. Динамика применения гидродинамических МУН и дополнительной добычи нефти на месторождениях Югры (с 2013 по 2019 ге., данные за 2019 2. - ожидаемые)

Fig. 6. Dynamics of application of hydrodynamic EOR methods and additional oil production at the fields of Yugra (since 2013 to 2019, data for 2019 expected)

Реально доказанный эффект при заводнении получен от применения потокоотклоняющих составов, главной особенностью которых является перераспределение потоков нагнетаемой жидкости из более в менее проницаемые зоны. При этом широкое применение получили эмульсионные, термотропные, осадко- гелеобразующие и гелеобразующие на основе полиакриамида (ПАА) потокотклоняющие технологии. Эффективность ПАА очень высокая, от 1000 до 5000 т дополнительной нефти на 1 т сухого полимера.

Отметим, что ПОТ имеют ряд серьезных ограничений по физическим параметрам пласта-коллектора и, в первую очередь, по температурному диапазону пласта (ограничения до $60{ }^{\circ} \mathrm{C}$ ), а также по «чувствительности» к составу воды, на основе которой проводится приготовление закачиваемого в пласт состава [14]. Основным косвенным признаком успешности применения ПОТ следует считать уменьшение обводненности получаемой продукции и изменение профиля приемистости нагнетательных скважин.

\section{Обработка призабойной зоны пласта}

В особую категорию МУН пластов следует отнести обработку призабойной зоны пласта $[6,7,15]$. В ТЭК Югры нашли промышленное применение химические, механические, тепловые, физические и вибрационные методы ОПЗ и их комбинации (термокислотная, пенокислотная и другие комбинации).

Наиболее часто используемым видом ОПЗ скважины на месторождениях Югры является кислотная обработка (КО) и ее модификации. Отметим, что область применения соляно-кислотной обработки (СКО) - это преимущественно карбонатные коллекторы, а область применения глино-кислотных обработок (ГКО) - терригенные коллекторы.

В промышленных масштабах на месторождениях округа применяются кислотные ванны, СКО под давлением, глинокислотная, пенокислотная и термокислотная обработки, также обработка нефтекислотными и другими, композиционными из нескольких кислот (серной, соляной, уксусной, лимонной, плавиковой, молочной и др.), эмульсиями.

На рис. 7 представлен анализ применения ОПЗ на месторождениях Югры, из которого следует, что за семилетний период на месторождениях Югры было проведено 44081 скважино-операций с эффективностью 0,5 тыс. т/скв-опер. За счет применения ОПЗ дополнительная добыча нефти составила 20172 тыс. т.

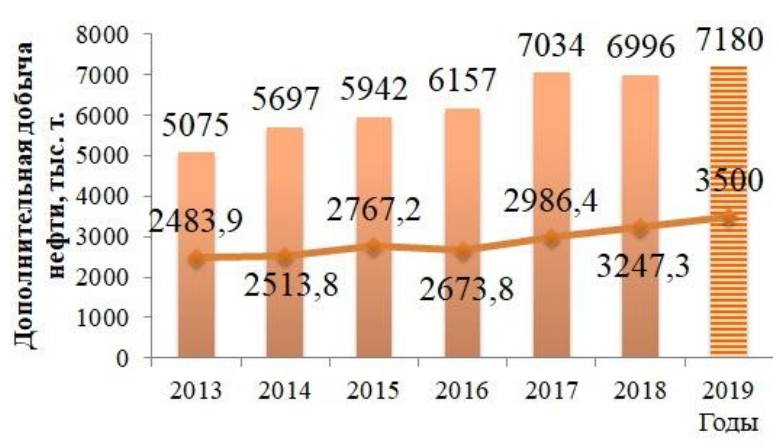

Скв-операций —-Дополнительная добыча нефти, тыс. т.

Рис. 7. Дополнительная добыча нефти за счет обработки призабойной зонь на месторождениях Югры (с 2013 nо 2019 га., данные за 2019 г. ожидаемье)

Fig. 7. Additional oil production due to bottomhole treatment at the fields of Yugra (since 2013 to 2019, data for 2019-expected)

\section{Гидроразрыв пласта}

Конечной целью применения ГРП является увеличение продуктивности нефтяных и приемистости нагнетательных скважин, вовлечения в разработку ТрИЗ, увеличение темпов отбора нефти и повышение КИН [16-18]

С конца пятидесятых годов прошлого века количество ГРП, проведенных на месторождениях СССР, превышало 1500 операций в год, однако после открытия «легкой» западно-сибирской нефти, добыча которой происходила без дополнительных методов стимулирования пласта, ГРП потеряла свою популярность. В Западной Сибири, в связи с изменением структуры запасов в сторону увеличения залежей с ТрИЗ, технологию ГРП начали внедрять в конце восьмидесятых годов прошлого века, а на сегодня она является самой массовой при добыче нефти в регионе. Отметим, что и сегодня на месторождениях Югры для проведения ГРП используется зарубежное оборудование и технологии. Поэтому главной целью нефтяников России на данный момент является не только повышение эффективности технологии и её 
удешевление, но и переход на отечественные технологии.

На сегодня (рис. 8) в производственном масштабе на предприятиях ТЭК Югры [18] применяется как стандартный ГРП, так и инновационные его варианты (сложнопрофильные, большеобъёмные и многостадийные ГРП, ГРП в горизонтальных скважинах и др.) в достаточно больших объемах, в том числе и на вновь вводимых скважинах с ТрИЗ.

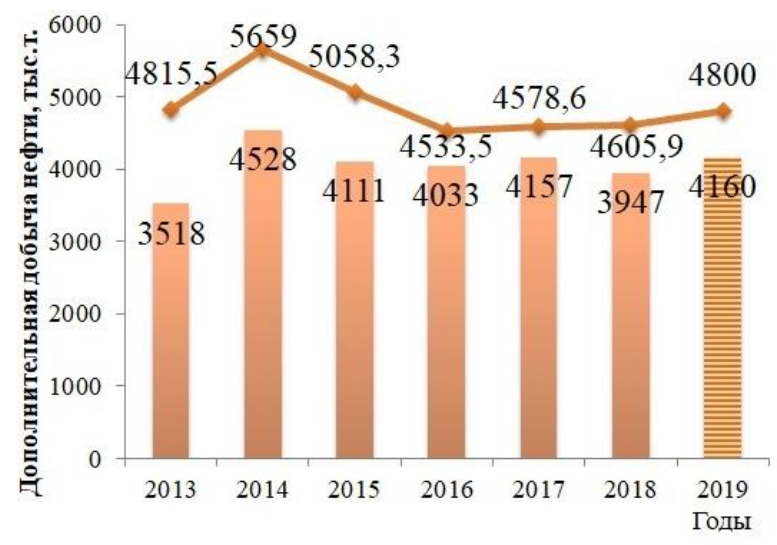

- Скв-операций —Дополннтельная добыча нефти, тыс. т.

Pис. 8. Эффективность применения ГРП на месторождениях Югры (с 2013 по 2019 гг., данные за 2019 г. - ожидаемые)

Fig. 8. Efficiency of hydraulic fracturing application at the fields of Yugra (since 2013 to 2019, data for 2019 expected)

\section{Бурение горизонтальных скважин}

Анализ применения методов увеличения КИН показывает, что наиболее рациональным в настоящее время в Югре становится бурение горизонтальных скважин. Это связано как с необходимостью повышения производительности и снижения сроков окупаемости строительства скважин, так и с тем, что добыча нефти из ТрИЗ в вертикальных стволах в современных экономических условиях неэффективна. Как показывает теория и практика, добыча нефти из горизонтальной скважины, большая часть которой проходит внутри коллектора, значительно повышает дебиты по нефти [19-21].

В результате моделирования и проверки в производственном режиме установлено [18], что оптимальная длина горизонтального участка ствола добывающей скважины для месторождений Среднего Приобья составляет 750 м. Среди основных преимуществ добычи из ГС можно выделить:

1) добыча из горизонтальных скважин нужна там, где по объективным причинам невозможно проводить бурение нефтяных скважин (водоохранные, санитарно-защитные зоны и объекты инфраструктуры);

2) «нагрузка» на единицу площади коллектора, связанная с добычей, значительно меньше, чем у вертикальной;

3) уменьшается образование конусов и «языков» обводнения;
4) вследствие расширения объёма дренирования пласта-коллектора к выработке приобщаются слабодренируемые зоны и пропластки, происходит увеличение коэффициента охвата пласта воздействием.

В настоящее время потенциал ГС при разработке нефтяных месторождений используется не полностью [22]. Эффективность разработки залежей с применением ГС возможна только в случае учета всей имеющейся геолого-геофизической информации для каждого конкретного месторождения и/или его блока. Для повышения эффективности выработки запасов нефти с использованием ГС основной задачей является дальнейший поиск оптимальных схем расположения стволов горизонтальных скважин. А это невозможно без создания постоянно действующей гидродинамической модели месторождения (залежи, пласта).

Анализ применения технологии добычи нефти из ГС на месторождениях Югры за период с 2013 по 2019 гг. (рис. 9) позволил нам сделать вывод о том, что наряду с положительными результатами, указанными выше, имеются и неудачные.

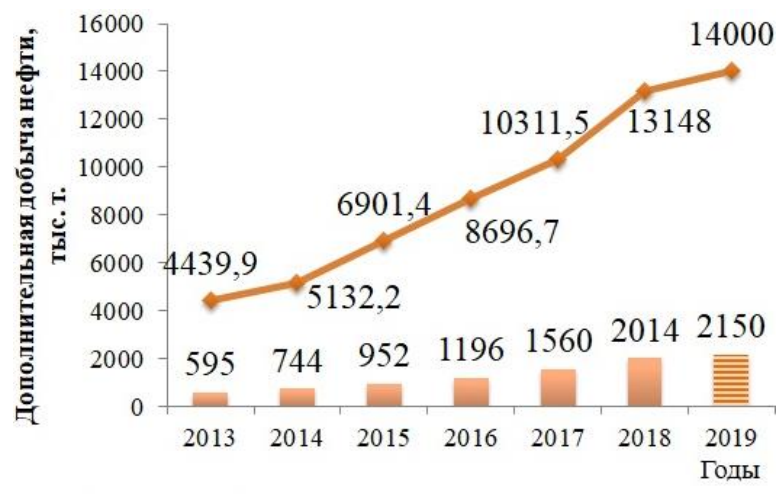

Скв-операций —Дополннтельная добыча нефти, тыс. т.

Pис. 9. Эффективность добычи нефти из горизонтальных скважин на месторождениях Югры (с 2013 по 2019 г2., данные за 2019 г. - ожидаемые)

Fig. 9. Efficiency of oil production from horizontal wells at the fields of Yugra (since 2013 to 2019, data for 2019 - expected)

Среди факторов, снижающих эффективность работы ГС, можно выделить:

1) концентрацию взвешенных частиц в нижней части ствола ГС;

2) кольматацию призабойной зоны скважины продуктами фильтрационного разрушения и диспергирование её глинистыми частицами потоком добываемой жидкости;

3) заиливание щелевого фильтра;

4) механическую деформацию ствола ГС.

\section{Зарезка боковых стволов}

Современные технологии направленного бурения позволяют оптимально использовать имеющийся, включая простаивающий, фонд скважин. Наиболее эффективным на сегодня методом восстановления 
бездействующих и повышения производительности малодебитных скважин является бурение бокового ствола [23 и др.]. Этот метод позволяет производить работы по строительству скважины точно по требуемому направлению, с любой глубины, при любых углах наклона. Особенно актуальной технология зарезки боковых стволов (ЗБС) становится при эксплуатации месторождений на поздней стадии разработки, когда строительство новых скважин становится нерентабельным в связи с их низкодебитностью.

Максимальный экономический эффект при использовании ЗБС можно получить при бурении многоствольных и разветвленно-горизонтальных скважин, что позволяет вовлечь в эксплуатацию простаивающий фонд нефтяных скважин, в которых остаточные запасы нефти в зоне их дренирования достаточно велики и которые нельзя возвратить в действующий фонд другими методами. Это характерно и для Югры, где даже на вновь вводимых в разработку месторождениях в последние годы наблюдается снижение эффективности эксплуатационного бурения и увеличение неработающего фонда скважин (рис. 10).

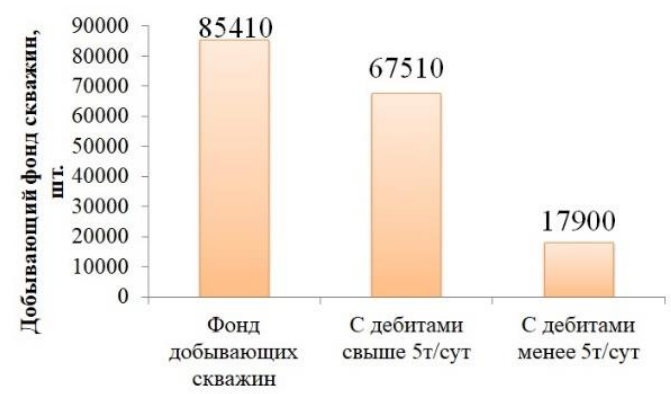

Pис. 10. Фонд добывающих скважин на месторождениях Югры (Департамент недропользования $и$ природных ресурсов Ханты-Мансийского автономного округа-Югры, 01.01.2019)

Fig. 10. Producing well stock at the fields of Yugra (Department of Subsurface Management \& Natural Resources of Khanty-Mansi Autonomous OkrugYugra, 01.01.2019)

Из рис. 10 следует, что на 01.01.2019 г. фонд низкодебитных (читай - нерентабельных) добывающих скважин составлял почти 18 тыс., или $21 \%$ от всего работающего фонда скважин. При этом фонд неработающих (простаивающих) скважин с дебитами менее 5 т/сут составил 8,5\% от общего фонда добывающих скважин, или более 7 тыс. скважин.

Что касается дебитов по нефти вновь вводимых в разработку скважин, то за 10 лет дебит снизился с 41 т/сут в 2008 г. до 28 т/сут в 2018 г., или на $32 \%$.

На рис. 11 представлена динамика объемов проведения ЗБС за семь лет. Отметим, что за этот период дополнительная добыча возросла с 4452 до 5500 т в год, т. е. на $24 \%$. Работы с применением технологии ЗБС в настоящее время дают максимальный рост эффективности. Это не скажешь о рассмотренных выше технологиях ГРП (рис. 8), где показатель дополнительной добычи за рассматриваемый период остался практически на уровне 2013 г.

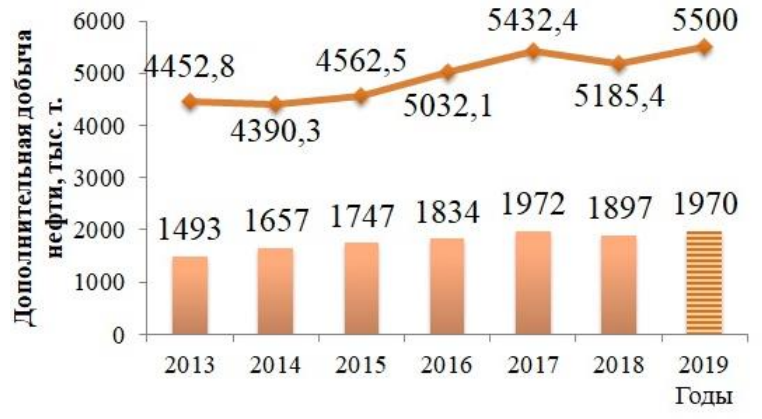

— Ск-операций $\leadsto$ - оополннтельная добыча нефтн, тыс. т.

Рис. 11. Динамика объемов проведения зарезки боковых стволов (ЗБС) и дополнительной добычи на месторождениях Югры (с 2013 по 2019 гг., данные за 2019 г. - ожидаемые)

Fig. 11. Dynamics of scope of Sidetracking (ST) performance and additional production at the fields of Yugra (since 2013 to 2019, data for 2019 - expected)

\section{Другие методы интенсификации добычи нефти}

Значительный объем работ при добыче нефти включают в себя геолого- технологические мероприятия (ГТМ) по оптимизации работы фонда скважин, в том числе дострелы, перестрелы, возвраты на вышележащие пласты, приобщения пластов, изоляционные работы, интенсификация добычи за счет снижение депрессии на пласт, а также перевод работы скважин на механическую добычу. Выше эти мероприятия были названы прочими методами - ПМ.

В каждой нефтяной компании на территории Югры названные технологии различны и зависят, прежде всего, от состояния фонда скважин того или иного объекта разработки. Общими причинами для проведения этих работ являются: полное истощение продуктивного пласта, прорыв контурных вод и практически $100 \%$ обводнение разрабатываемого объекта, дегазация продуктивного горизонта, а также многочисленные осложнения, связанные с добычей нефти. На рис. 12 представлена динамика объемов ГТМ за семилетний период.

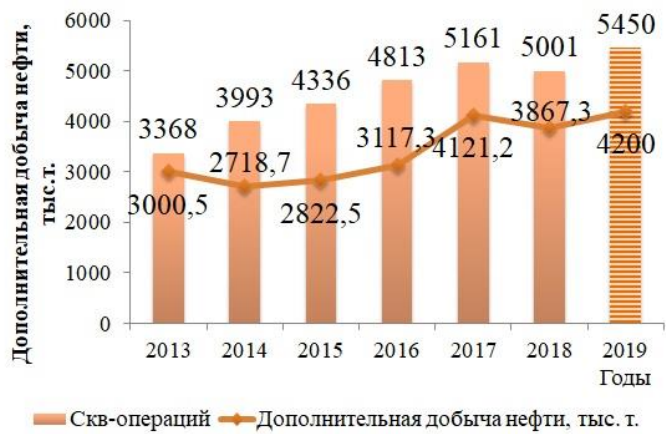

Pис. 12. Динамика дополнительной добычи нефти за счет ГТМ по оптимизации работы фонда скважин на месторождениях Югры (с 2013 по 2019 ге., данные за 2019 г. - ожидаемые)

Fig. 12. Dynamics of additional oil production due to Well Interventions Operations (WIO) for optimization of well stock work at the fields of Yugra (since 2013 to 2019, data for 2019 - expected) 


\section{Заключение}

В Ханты-Мансийском автономном округе-Югре наметилась положительная тенденция стабилизации годовой добычи нефти на уровне $235-236$ млн т. При этом доля дополнительной добычи нефти за счет применения методов увеличения нефтеотдачи и интенсификации добычи увеличилась с 9,4 \% в 2013 г. до $16,0 \%$ в 2019 г.

Наиболее массовыми среди используемых в промышленных масштабах методами интенсификации добычи и повышения нефтеотдачи являются физикохимические - ФХМ, обработки призабойной зоны ОПЗ и гидродинамические - ГДМ. А самыми эффективными методами, с точки зрения дополнительной добычи, являются бурение горизонтальных скважин БГС, зарезка боковых стволов - ЗБС и гидроразрыв пласта - ГРП.

\section{СПИСОК ЛИТЕРАТУРЫ}

1. Новостная лента ИА Neftegaz.ru от 28 августа 2019 г. URL: https://neftegaz.ru/news/dobycha/483197-yugra-mozhet-statpilotnym-regionom-dlya-aprobatsii-novykh-tekhnologiypovysheniya-nefteotdachi-/ (обращение 02.12.2019).

2. Оценка добычного потенциала нефтяных месторождений ХМАО - Югры в современных условиях / И.П. Толстолыткин, Н.В. Мухарлямова, Т.Н. Печерин, М.В. Стрельченко // Пути реализации нефтегазового потенциала ХМАО. Двадцать вторая научно-практическая конференция. Т. 1. - ХантыМансийск: ИздатНаукаСервис, 2019. - С. 15-23.

3. Развитие нефтегазового комплекса Югры, трудноизвлекаемые запасы / С.Г. Кузьменков, В.И. Исаев, В.И. Булатов, Р.Ш. Аюпов, Н.О. Игенбаева, Ю.А. Кузьмин, П.А. Стулов // Известия Томского политехнического университета. Инжиниринг георесурсов. - 2018. - Т. 329. - № 11. - С. 103-113.

4. Идентификация трудноизвлекаемых запасов нефти Югры С.Г. Кузьменков, Ю.А. Кузьмин, П.А. Стулов, Р.Ш. Аюпов, В.И. Булатов, Н.О. Игенбаева, В.И. Исаев, Г.А. Лобова // Геофизический журнал. - 2018. - Т. 41. - № 4. - С. 114-124.

5. Сургучев Л.М. Обзор третичных методов увеличения нефтеотдачи // Нефтяное хозяйство. - 2001. - № 5. - С. 50-54.

6. Romero-Zeron L. Chemical Enhanced Oil Recovery (cEOR) Practical Overview. - Fredericton: IntechOpen, 2016. - 200 p.

7. Hascakir B. Introduction to thermal Enhanced Oil Recovery (EOR) // Journal of Petroleum Science and Engineering, special issue. - 2017. - V. 154. - P. 438-441.

8. Сопоставление выработки запасов нефти основными недропользователями ХМАО-Югры / А.В. Оренбуркин, Н.Ю. Галкин, Н.Д. Марьина, Н.В. Козельская // Пути реализации нефтегазового потенциала ХМАО. Двадцать вторая научнопрактическая конференция. Т. 2. - Ханты-Мансийск: ИздатНаукаСервис, 2019. - С. 44-52.

9. Application of Foam for Gas and Water Shut-off: Review of Field Experience / S.A. Zhdanov, A.V. Miyan, L.M. Surguchev, L.M. Castanier, J.E. Hanssen // European Petroleum Congress. Milan, Italy: Society of Petroleum Engineers, 1996. - P. 377-388.

10. Владимиров И.В. Нестационарные технологии нефтедобычи (этапы развития, современное состояние и перспективы). - М.: ОАО ВНИИОЭНГ, 2004. - $216 \mathrm{c}$

11. Standnes D.C., Skjevrak I. Literature review of implemented polymer field projects // Journal of Petroleum Science and Engineering. - 2014. - V. 122. - P. 761-775.

12. Delamaide E. Comparison of steam and polymer injection for the recovery of heavy oil // SPE Western Regional Meeting. Bakersfield, California, USA, 2017. - Paper SPE 185728.
Массовое внедрение мероприятий по интенсификации добычи нефти на разрабатываемых месторождениях является наиболее актуальной проблемой и требует усиления научного обоснования оптимальных условий строительства и эксплуатации систем разработки.

Для стимулирования геологоразведки и увеличения добычи нефти, включая ТрИЗ, за счет внедрения в производство технологий и технических приемов интенсификации необходимо совершенствование нормативно-правового обеспечения недропользования [4].

Учитывая, что доля ТрИЗ нефти в Югре составляет в среднем около $60 \%$, а по некоторым компаниям достигает 75-80\%, альтернативы развитию третичных методов (ГС, ЗБС, ГРП, ФХМ, ОПЗ, ГДМ) на месторождениях Югры сегодня просто нет.

13. Emulsification and improved oil recovery with viscosity reducer during steam injection process for heavy oil / Zhengbin Wu, Liu Huiqing, Xue Wang, Zequan Zhang // Journal of Industrial and Engineering Chemistry. - 2018. - V. 61. - P. 348-355.

14. Опыт применения потокоотклоняющих технологий повышения нефтеотдачи пластов с использованием реагента «Продукт № 1» на основе титанового коагулянта / В.В. Халин, Р.Ф. Мазитов, Е.Н. Мальшаков, В.Ю. Хорюшин, Н.А. Демяненко // Пути реализации нефтегазового потенциала ХМАО. Двадцать вторая научно-практическая конференция. Т. 2. Ханты-Мансийск: ИздатНаукаСервис, 2019. - С. 53-66.

15. Закиров С.Н., Закиров И.С. Новый подход к разработке нефтегазовых залежей. - М.: Изд-во «ИРЦ Газпром», 1996. $51 \mathrm{c}$.

16. Economides M., Oligney R., Valkó P. Unified fracture design: bridging the gap between theory and practice. - Alvin, Texas: Orsa Press, 2002. -25 p.

17. Fracability evaluation in shale reservoirs - an integrated petrophysics and geomechanics approach / X. Jin, S.N. Shah, J. Roegiers, B. Zang // SPE Hydraulic Fracturing Technology Conference. - Woodlands, TX, USA, 2014. - Paper SPE 168589.

18. Черевко М.А., Янин А.Н., Янин К.Е. Разработка нефтяных месторождений Западной Сибири горизонтальными скважинами с многостадийными гидроразрывами пласта. - Тюмень; Курган: Зауралье, 2015. - 268 с.

19. Саунин В.И., Шаламов М.А., Ягафаров А.К. Эффективность строительства и эксплуатации горизонтальных скважин на Самотлорском месторождении (пласт АВ 1/1-2 «рябчик») // Нефтепромысловое дело. - 2007. - № 11. - С. 59-62.

20. Akangbou H.N., Burby M. Nasr Gh. Effectively optimizing production of horizontal wells in homogeneous oil reservoirs // Journal of Petroleum Science and Engineering. - 2017. - V. 150. P. $128-136$.

21. Near-wellbore modeling of a horizontal well with Computational Fluid Dynamics / M.L. Szanyi, C.S. Hemmingsen, Wei Yan, J.H. Walther, S.L. Glimberg // Journal of Petroleum Science and Engineering. - 2018. - V. 160 - P. 119-128.

22. Закиров И.С., Владимиров И.В. Соотношение числа горизонтальных и вертикальных скважин при определении плотности сетки скважин // Нефтяное хозяйство. - 2008. - № 1. - С. 66-67.

23. Методика проектирования боковых стволов скважин на месторождениях Западной Сибири с учетом поздней стадии их разработки / Р.Р. Исхаков, С.А. Воронов, А.И. Ермолаев, В.В. Воронова // Нефтяное хозяйство. - 2012. - № 1. - С. 38-41.

Поступила 2.02.2020 г. 
Информация об авторах

Кузьменков С.Г., доктор геолого-минералогических наук, профессор Института нефти и газа Югорского государственного университета.

Аюпов Р.Ш., кандидат технических наук, доцент Института нефти и газа Югорского государственного университета.

Новиков М.В., заместитель директора Департамента недропользования и природных ресурсов ХантыМансийского автономного округа-Югры.

Исаев В.И., доктор геолого-минералогических наук, профессор отделения геологии Инженерной школы природных ресурсов Национального исследовательского Томского политехнического университета.

Лобова Г.А., доктор геолого-минералогических наук, профессор отделения геологии Инженерной школы природных ресурсов Национального исследовательского Томского политехнического университета.

Стулов П.А., первый заместитель директора АУ «Научно-аналитический центр рационального недропользования им. В.И. Шпильмана».

Бутин B.C., заведующий лабораторией отделения мониторинга разработки нефтяных месторождений АУ «Научно-аналитический центр рационального недропользования им. В.И. Шпильмана».

Acmaneнко E.O., кандидат экономических наук, доцент Института цифровой экономики Югорского государственного университета. 
УДК 662.276.53(571.12)

\section{ENHANCED OIL RECOVERY METHODS AT FIELDS OF YUGRA}

\author{
Stanislav G. Kuzmenkov', \\ ksg.1948@ya.ru
}

\section{Roman Sh. Ayupov',} ayupovrsh@gmail.com

Maksim V. Novikov², NovikovMV@admhmao.ru

Valery I. Isaev, isaevvi@tpu.ru

1 Yugra State University,

16, Chekhov street, Khanty-Mansiysk, 628012, Russia.

2 Department of Subsurface Management \& Natural Resources of Khanty-Mansi Autonomous Okrug-Yugra, 2, Studencheskaya street, Khanty-Mansiysk, 628007, Russia.

${ }^{3}$ National Research Tomsk Polytechnic University, 30, Lenin avenue, Tomsk, 634050, Russia.

${ }^{4}$ Research and Analytical Center for the Rational Use of the Subsoil named after V.I. Shpilman, 2, Studencheskaya street, Khanty-Mansiysk, 628007, Russia.

\author{
Galina A. Lobova ${ }^{3}$, \\ lobovaga@tpu.ru
}

Petr A. Stulov4, StulovPA@nacrn.hmao.ru

Vitaliy S. Butin 4 , butinvs@nacrn.hmao.ru

\section{Elena O. Astapenko1,} fedorov-elena@yandex.ru

The relevance. State Register of Reserves booked 482 fields of raw hydrocarbons (in the order of 12 billion tonnes of recoverable reserves) in Yugra. 273 fields are at production stage, 210 fields are at different stages of research. Current depletion of producing fields is $61 \%$ and their current water cut is above $85 \%$. Modern stage is characterized by decreasing production rate virtually at all objects of oil recovery and increasing of hard to recover reserves component to 65-70\%. The main task for fuel and energy manufacturers of Yugra - the major base of raw hydrocarbon materials and recovery in Russia - is to stabilize oil production on the reached in 2018 level at 235-236 million tonnes per year. Solving of this problem is impossible without application of innovative enhanced oil recovery technologies.

The main aim of the research is the efficiency analysis (from viewpoint of additional production) of tertiary technologies of enhanced oil recovery factor at fields of Yugra, which were introduced while operation.

Object: peculiarities and field-geological results of enhanced oil recovery methods at fields of Yugra (2013-2019): physical and chemical, hydrodynamic, hydraulic fracturing, horizontal drilling, sidetracking, bottomhole treatment and other methods - well interventions operations for optimization of well stock work.

Methods. Retrospective comparative analysis of performed enhanced oil recovery well operations and additional oil production: physical and chemical - 48016, hydrodynamic - 23374, hydraulic fracturing - 28454, horizontal drilling - 11225, sidetracking - 9010, bottomhole treatment - 44081, well interventions operations - 32123 operations.

Results. Field-geological and statistical reporting data of Research and Analytical Center for the Rational Use of the Subsoil named after V.I. Shpilman and Department of Subsurface Management \& Natural Resources of Khanty-Mansi Autonomous Okrug-Yugra was analyzed. A trend of stabilization of annual oil recovery is emerged in Yugra. Thereat, a fraction of additional oil production was increased from 9,4 \% in 2013 to 16,0 \% in 2019 due to application of enhanced oil recovery methods and well interventions operations. The major methods of intensification of production and enhanced oil recovery are physical and chemical, bottomhole treatment and hydrodynamic. The most effective methods, which provide additional production, are horizontal drilling, sidetracking and hydraulic fracturing. Application of enhanced oil recovery methods requires enhancement of scientific and technical explanation of optimal conditions of construction and operation of development systems. The fraction of hard to recover reserves of oil is about $60 \%$ in average and for several companies is $75-80 \%$, for this reason today there is no alternative to development of tertiary enhanced oil recovery methods at the fields of Yugra.

\section{Key words:}

Hard to recover reserves, oil recovery factor, enhanced oil recovery methods, retrospective analysis, Yugra.

\section{REFERENCES}

1. Novostnaye lenta IA Neftegaz.ru ot 28 avgusta $2019 \mathrm{~g}$. [News feed of media outlet Neftegaz.ru of 28 August, 2019]. Available at: https://neftegaz.ru/news/dobycha/483197-yugra-mozhet-statpilotnym-regionom-dlya-aprobatsii-novykh-tekhnologiypovysheniya-nefteotdachi- $/$ (accessed 2 December 2019).

2. Tolstolytkin I.P., Mukharlyamova N.V., Pecherin T.N., Strelchenko M.V. Otsenka dobychnogo potentsiala neftyanykh mestorozhdeniy KhMAO-Yugry v sovremennykh usloviyakh [Estimation of production potential of oil fields of Khanty-Mansi Autonomous Okrug-Yugra in modern conditions]. Puti realizatsii neftegazovogo potentsiala KhMAO. Dvadtsat vtoraya nauchno- prakticheskaya konferentsiya [Ways of oil-and-gas potential implementation of Khanty-Mansi Autonomous Okrug. $22^{\text {nd }}$ Research-to-Practice Conference]. Khanty-Mansiysk, IzdatNaukaServis Publ., 2019. Vol. 1, pp. 15-23.

3. Kuzmenkov S.G., Isaev V.I., Bulatov V.I., Ayupov R.Sh., Eginbaeva N.O., Kuzmin Yu.A., Stulov P.A. Development of Yugra oil and gas complex, hard-to-extract reserves. Bulletin of the Tomsk Polytechnic University. Geo Assets Engineering, 2018, vol. 329, no. 11, pp. 103-113. In Rus.

4. Kuzmenkov S.G., Kuzmin Yu.A., Stulov P.A., Ayupov R.Sh., Bulatov V.I, Igenbaeva N.O., Isaev V.I., Lobova G.A. Identification of hard to recover reserves of Ugra oil. Geofizicheskii zhurnal, 2018, vol. 41, no. 4, pp.114-124. In Rus. 
5. Surguchev L.M. Obzor tretichnykh metodov uvelicheniya nefteotdachi [Overview of tertiary enhanced oil recovery methods] Neftyanoe hozyaystvo, 2001, no. 5, pp. 50-54.

6. Romero-Zeron L. Chemical Enhanced Oil Recovery (cEOR). Practical Overview. Fredericton, IntechOpen, 2016. 200 p.

7. Hascakir B. Introduction to thermal Enhanced Oil Recovery (EOR). Journal of Petroleum Science and Engineering, special issue, 2017, vol. 154, pp. 438-441.

8. Orenburkin A.V., Galkin N.Yu., Marina N.D., Kozelskaya N.V. Sopostavlenie vyrabotki zapasov nefti osnovnymi nedropolzovatelyami KhMAO-Yugry [Comparison of oil reserves production by major subsoil users of Khanty-Mansi Autonomous OkrugYugra]. Puti realizatsii neftegazovogo potentsiala KhMAO. Dvadtsat vtoraya nauchno-prakticheskaya konferentsiya [Ways of oil-and-gas potential implementation of Khanty-Mansi Autonomous Okrug. 22 ${ }^{\text {nd }}$ Research-to-Practice Conference]. KhantyMansiysk, IzdatNaukaServis Publ., 2019. Vol. 2, pp. 44-52.

9. Zhdanov S.A., Miyan A.V., Surguchev L.M., Castanier L.M., Hanssen J.E. Application of Foam for Gas and Water Shut-off: Review of Field Experience. European Petroleum Congress. Milan, Italy, Society of Petroleum Engineers, 1996. pp. 377-388.

10. Vladimirov I.V. Nestatsionarnye tekhnologii neftedobychi (etapy razvitiya, sovremennoe sostoyanie i perspektivy) [Unsteady technologies of oil production (development stages, the current state and prospects)]. Moscow, OAO VNIIOYeNG Publ., 2004. 216 p.

11. Standnes D.C., Skjevrak I. Literature review of implemented polymer field projects. Journal of Petroleum Science and Engineering, 2014, vol. 122, pp. 761-775.

12. Delamaide E. Comparison of steam and polymer injection for the recovery of heavy oil. SPE Western Regional Meeting. Bakersfield, California, USA, 2017. Paper SPE 185728.

13. Zhengbin $\mathrm{Wu}$, Liu Huiqing, Xue Wang, Zequan Zhang. Emulsification and improved oil recovery with viscosity reducer during steam injection process for heavy oil. Journal of Industrial and Engineering Chemistry, 2018, vol. 61, pp. 348-355.

14. Halin V.V., Mazitov R.F., Malshakov E.N., Khoryushin V.Yu., Demyanenko N.A. Opyt primeneniya potokootklonyayushchikh tekhnologiy povysheniya nefteotdachi plastov $\mathrm{s}$ ispolzovaniem reagenta «Produkt №1» na osnove titanovogo koagulyanta [Experience of diverter enhanced oil recovery technologies with usage of reagent «Product no. 1» on the base of titanium coagulant]. Puti realizatsii neftegazovogo potentsiala KhMAO. Dvadtsat vtoraya nauchno-prakticheskaya konferentsiya [Ways of oil-and-gas potential implementation of Khanty-Mansi Autonomous Okrug. $22^{\text {nd }}$ Research-to-Practice Conference]. Khanty-Mansiysk, IzdatNaukaServis, 2019. Vol. 2, pp. 53-66.

15. Zakirov S.N., Zakirov I.S. Novy podkhod $k$ razrabotke neftegazovykh zalezhey [New approach to oil-and-gas pool development]. Moscow, IRC Gazprom Publ., 1996. 51 p.

16. Economides M., Oligney R., Valkó P. Unified fracture design: bridging the gap between theory and practice. Alvin, Texas, Orsa Press, 2002. $25 \mathrm{p}$.

17. Jin X., Shah S.N., Roegiers J., Zang B. Fracability evaluation in shale reservoirs - an integrated petrophysics and geomechanics approach. SPE Hydraulic Fracturing Technology Conference. Woodlands, Texas, USA, 2014. Paper SPE 168589.

18. Cherevko M.A., Yanin A.N., Yanin K.E. Razrabotka neftyanykh mestorozhdeniy Zapadnoy Sibiri gorizontalnymi skvazhinami s mnogostadiynymi gidrorazryvami plasta [Development of oil fields of Western Siberia with horizontal wells by multistage hydraulic fracturing]. Tumen; Kurgan, Zauralye Publ., 2015. 268 p.

19. Saunin V.I., Shalamov M.A., Yagafarov A.K. Effektivnost stroitelstva i ekspluatatsii gorizontalnykh skvazhin na Samotlorskom mestorozhdenii (plast AV 1/1-2 «ryabchik») [Efficiency of construction and operation of horizontal wells on Samotlor Field (AB 1/1-2 formation «Ryabchik»)]. Neftepromyslovoe delo, 2007, no. 11 , pp. 59-62.

20. Akangbou H.N., Burby M., Nasr Gh. Effectively optimizing production of horizontal wells in homogeneous oil reservoirs. Journal of Petroleum Science and Engineering, 2017, vol. 150, pp. 128-136.

21. Szanyi M.L., Hemmingsen C.S., Wei Yan, Walther J.H., Glimberg S.L. Near-wellbore modeling of a horizontal well with Computational Fluid Dynamics. Journal of Petroleum Science and Engineering, 2018, vol. 160, pp. 119-128.

22. Zakirov I.S., Vladimirov I.V. Horizontal and vertical wells relation at wells density grid determination. Oil Industry, 2008, no. 8, pp. 66-67. In Rus.

23. Iskhakov R.R., Voronov S.A., Ermolaev A.I., Voronova V.V. Methodical approaches of second wellbore designing at the last stage of Western Siberian fields development. Oil Industry, 2012, no. 1, pp. 38-41. In Rus.

Received: 2 February 2020.

\section{Information about the authors}

Stanislav G. Kuzmenkov, Dr. Sc., professor, Yugra State University.

Roman Sh. Ayupov, Cand. Sc., associate professor, Yugra State University.

Maksim V. Novikov, deputy director, Department of Subsurface Management \& Natural Resources of Khanty-Mansi Autonomous Okrug-Yugra.

Valery I. Isaev, Dr. Sc., professor, National Research Tomsk Polytechnic University.

Galina A. Lobova, Dr. Sc., professor, National Research Tomsk Polytechnic University.

Petr A. Stulov, first deputy director, Research and Analytical Center for the Rational Use of the Subsoil named after V.I. Shpilman.

Vitaliy S. Butin, chief of laboratory, Research and Analytical Center for the Rational Use of the Subsoil named after V.I. Shpilman.

Elena O. Astapenko, Cand. Sc., associate professor, Yugra State University. 